\title{
Effect of Fruit Bagging on Eggplant Fruit and Shoot Borer for Quality Eggplant Production
}

\author{
AKM Quamruzzaman, Ferdouse Islam, M. Nazim Uddin, and M. Shahadath Hossain
}

\section{ABSTRACT}

The study was tested the technical feasibility of bagging eggplant fruits during production to protect them against Eggplant fruit and shoot borer (EFSB) following randomized complete block with 6 treatments. Highest number of marketable fruits per plant was produced by imported white bag (12.33), which was followed by butter paper bag (10.67). Maximum aborted fruit was obtained from the imported brown bag (23.33\%) and HDPE bag $(20.00 \%)$. The highest average fruit weight $(363.33 \mathrm{~g})$ was obtained from fruits bagged with Imported white, while maximum fruit length and fruit diameter was also produced from imported white bag $(15.27 \mathrm{~cm}$ and 11.23 $\mathrm{cm}$, respectively). Zero percent damage by eggplant fruit and shoot borer was produced by imported brown bag, imported white bag and butter paper bag, while higher infection was observed in open fruit (control) $(17.70 \%)$, HDPE bag (11.70 \%). Bagging eggplant fruit produced 38.78 to $58.20 \mathrm{t} / \mathrm{ha}$, while open fruit (control) produced only $35.66 \mathrm{t} / \mathrm{ha}$. The highest calculated fruit yield 58.20 tons/ha was estimated from imported white bag and other bagging fruits were local brown bag (46.74 t/ha), HDPE bag (45.00 t/ha), butter paper bag (43.23 t/ha). The bagging of eggplant fruits with imported white bag and butter paper bag were more effective in reducing damage by eggplant fruit and shoot borer than the other bagging treatments and the control. These two treatments produced higher number of consumers preferred fruit, without negative effects on the color of the skin, fresh weight and fruit abortion, thus resulting in higher economic gains.

Keywords: Eggplant, eggplant fruit and shoot borer (EFSB), Leucinodes orbonalis, fruit bagging, marketable eggplant yield.

\section{INTRODUCTION}

Eggplant (Solanum melongena L.) is one of the most important, widely and round the year cultivated popular vegetable in Bangladesh. It occupies an area of about 50,415 hectares with a total production of $5,04,817$ tones. The average yield being only 10.013 tones per hectare [1], which is very low as compared to that in other eggplant growing countries. This low yield may be either due to lack of good variety or proper management. In eggplant, several biotic factors viz., pest and diseases are responsible to reduce the yield, amongst them eggplant fruit and shoot borer (EFSB), Leucinodes orbonalis, is the most damaging pest of eggplant in South and Southeast Asia especially in Bangladesh. Its larvae feed inside eggplant fruit, making the fruit unmarketable and unfit for human consumption. To combat this problem several attempts have been taken so far. Farmers are currently using too many toxic chemicals and applying them too frequently (up to 100 times) to control EFSB. This excessive pesticide usage threatens the health of farmers and consumers, besides making eggplant fruit more costly to consumers. In the meantime, the insect is becoming tolerant to the chemicals, making it more difficult to control. To address these chemical pesticides now a day's farmers are farmers.
Submitted : March 05, 2021

Published : April 13, 2021

ISSN: $2684-1827$

DOI: 10.24018 /ejfood.2021.3.2.259

\section{AKM Quamruzzaman}

Olericulture Division, Horticulture Research Center, Bangladesh Agricultural Research Institute, Bangladesh.

(e-mail: akmqzs@gmail.com)

F. Islam

Olericulture Division, Horticulture Research Center, Bangladesh Agricultural Research Institute, Bangladesh.

(e-mail: ive_bari@yahoo.com)

M. Nazim Uddin

Olericulture Division, Horticulture Research Center, Bangladesh Agricultural Research Institute, Bangladesh.

(e-mail: nazim.68@gmail.com)

M. Shahadath Hossain

Entomology Section, Horticulture Research Center, Bangladesh Agricultural Research Institute, Bangladesh.

(e-mail: mshahadath67@ gmail.com)

*Corresponding Author

using sex pheromone trap, bio pesticide, botanical pesticides, clean cultivation etc. But no one can reduce the EFSB for the

Very recently few farmers are starting fruit bagging in their eggplant in Bangladesh and getting better result in terms of quality fruits. They wrapped each eggplant with a specially-made plastic bag imported from China soon after it started growing. That way, the farmers not only managed to save additional costs on chemical pesticides to control EFSB, but also trying to offer 100 percent chemical-free eggplants to the consumers. So, it is essential to validate the imported brown bag, imported white bag along with locally available plastic and paper bags. So, there is a great scope to get safe and quality eggplant using fruit bagging. The present study was undertaken to study the imported brown bag, imported white bag along with locally available plastic and paper bags to control EFSB. So, this study has been undertaken to find out the suitable bagging material to control EFSB and also higher yield with quality fruits. 


\section{MATERIALS AND METHODOLOGY}

\section{A. Experimental Site}

The experiment was conducted at the experimental farm of Joydebpur during the winter of 2018-19. The experimental field was at $23.9917^{\circ} \mathrm{N}$ Latitude and $90.4124^{\circ}$ E Longitudes having an elevation of $8.2 \mathrm{~m}$ from sea level under agroecological zone (AEZ) 28 [2]. The experimental site is situated in the sub-tropical climatic zone and characterized by scanty rainfall during the experimental time. The average minimum and maximum temperature were $18.37{ }^{\circ} \mathrm{C}$ and $29.37^{\circ} \mathrm{C}$ and the average relative humidity varied from 55.55 to $75.70 \%$. The soil of the experimental field was sandy clay loam in texture having a $\mathrm{pH}$ range around 6.0.

\section{B. Treatments and Plant Materials}

Five bagging materials were used in this study viz., i) Imported brown bag- (thick paper bag and brown colored with black colour inner side) ii) Local brown bag iii) Imported white bag iv) Butter paper bag (locally available white cellophane paper bags) v) HDPE bag (transparent plastic) vi) Open fruit (Un-bagging) (control) included in the study. The seeds were sown on the seedbed on 05 September 2018. Thirty days old seedlings were transplanted in the main field on 04 October, 2018.

\section{Experimental Design and Layout}

The experiment was laid out in a RCB design with three replications. The unit plot size was $7.0 \times 0.70 \mathrm{~m}$ and 10 plants were accommodated in a plot with a plant spacing of $70 \mathrm{~cm}$ apart in single row maintaining a row-to-row distance of $1 \mathrm{~m}$ with $30 \mathrm{~cm}$ drain.

\section{Land Fertilization}

The land was fertilized with organic fertilizer, N, P, K, S, Zn and B @ 3,000 100, 30, 75, 13, 1.5 and 0.8 kg/ha, respectively. One third of the organic fertilizer and half of $\mathrm{P}$ and full of $\mathrm{S}, \mathrm{Zn}$ and $\mathrm{B}$ were applied during final land preparation. Rest of organic fertilizer and $\mathrm{P}$ and $1 / 3$ of $\mathrm{K}$ were applied as basal in pit. Entire amount of $\mathrm{N}$ and rest of $\mathrm{K}$ were applied in four equal installments starting from 20 days after transplanting. Rest three installments were applied at vegetative, flowering and initial fruiting stage. Irrigation, weeding, crop protection measures and other intercultural operations were done following standard practice.

\section{E. Data Collection and Statistical Analysis}

Data on days to 1 st harvest, number of marketable fruit, aborted fruit $(\%)$, average fruit weight $(\mathrm{g})$, fruit length $(\mathrm{cm})$, Fruit diameter $(\mathrm{cm})$, fruit yield per plant $(\mathrm{kg})$, eggplant fruit and shoot borer (EFSB) infection (\%), spotted/ scratched fruits $(\%)$, fruit skin colour and fruit yield ( $\mathrm{t} / \mathrm{ha}$ ) were recorded from five randomly selected plants per entry per replication. The recorded data for different characters were analyzed statistically using 'MSTAT-C' program to find out the significance of variation among the treatments. The analysis of variance (ANOVA) was performed by F-test, while the significance of difference between the pairs of treatment means were evaluated by the Duncan's Multiple Range Test (DMRT) test at 5\% and $1 \%$ level of probability [3].

\section{DISCUSSION}

Different types of fruit bagging had significant effect in brinjal fruit development. The development of fruit bagged either with imported white bag (106.00 days) or butter paper bag (107.00 days) to first harvest exhibited about a 3.67-4.67 days early compared to imported brown bag (110.67 days) (Table I). Highest number of marketable fruits per plant was produced by imported white bag (12.33), which was followed by butter paper bag (10.67), local brown bag, HDPE bag, open fruit (10.33) and lowest number was produced by imported brown bag (9.67). The low production was due to its thick paper bag and brown colored with black colour inner side. Maximum aborted fruit was obtained from the imported brown bag (23.33\%), which was statistically similar with HDPE bag $(20.00 \%)$. Rest all bags including open fruit (control) were not responsible for any aborted fruit, which suggest that the material of these bags affect the fruit abortion. [4] measured similar production rate of fresh mass for bagged and non-bagged tomato fruit. Average fruit weight is important for commercial production and it is an important factor in market competitiveness [5]. Fruit weight mainly differed for those with higher fruit diameter. The highest average fruit weight $(363.33 \mathrm{~g})$ was obtained from fruits bagged with Imported white, while statistically similar result was obtained from local brown bag (348.33 g). Lower weighed fruit was obtained from open fruit (control) $(265.00 \mathrm{~g})$ and imported brown bag (308.33 g). Maximum fruit length was produced from imported white bag (15.27 $\mathrm{cm}$ ), which was statistically similar with butter paper bag $(15.07 \mathrm{~cm})$, HDPE bag $(14.80 \mathrm{~cm})$ and local brown bag $(14.70 \mathrm{~cm})$. The lowest lengthen fruit was from imported brown bag $(14.42 \mathrm{~cm})$ due to its less photosynthesis occur.

Fruit diameter is an important character which plays important role towards higher yield. Higher diameter fruit was obtained from imported white bag $(11.23 \mathrm{~cm})$, followed by local brown bag $(10.75 \mathrm{~cm})$, imported brown bag $(10.67$ $\mathrm{cm})$, HDPE bag $(10.30 \mathrm{~cm})$, lowest diameter fruit was obtained by open fruit (control) $(9.83 \mathrm{~cm})$. The highest fruit yield per plant $(4.48 \mathrm{~kg}$ ) was obtained by imported white bag, which was calculated from number of marketable fruit and average fruit weight. In both cases the imported white bag performed far better, while other bagging fruits were 2.98 to $3.60 \mathrm{~kg} /$ plant and open fruit (control) produced only $2.74 \mathrm{~kg}$. Zero percent damage by eggplant fruit and shoot borer (EFSB) was produced by imported brown bag, imported white bag and butter paper bag, which ensures higher fruit production with higher quality. Because the bagging materials were different, so there was an impact in fruit colour.

Higher infection was observed in open fruit (control) (17.70 \%), HDPE bag (11.70\%). Local brown produced 6.00 $\%$ infected fruits due to rupture of bag was seen at middle stage of fruit maturity. This finding agrees with the reduced damage inflicted by $N$. elegantalis on clusters of tomatoes bagged with paper glessine compared to insecticide treatment [6]. Efficient control resulted from greater protection by bags, which were sealed to prevent the penetration of this insects (i.e., oviposition on the fruits). Also, [7] observed that a protective paper cone open at the bottom reduced damage by $N$. elegantalis by $70 \%$, and that by $H$. zea by $40 \%$, but this type of protection was not 
effective against $T$. absoluta. Similar results were observed by [8] with fruits of $A$. crassiflora bagged to protect them against fruit borers; and these authors found that paper bags were destroyed by rain thus allowing a high level of insect damage. Spotted/ scratched fruits were seen maximum in open fruit (control) (18.45\%) due to its open condition creates scratch with neighbor twigs which was followed by HDPE bag (14.65\%). Beside these, other bagged eggplants produced spotless fruits, which ensure high quality of eggplants. In case of fruit skin colour, imported brown bag produced white-colored fruits which was discolored type, which has no market value, while rest all bagging and nonbagging produced true colored "Light green" colored fruits. In our study, bagging eggplant fruit produced 38.78 to $58.20 \mathrm{t} / \mathrm{ha}$, while open fruit (control) produced only 35.66 t/ha. The highest calculated fruit yield 58.20 tons/ha was estimated from imported white bag. Open pollinated eggplant varieties of oval shaped fruit reached an average yield of 30-45 tons/ha with an average fruit weight of 200$250 \mathrm{~g}$, suitable for marketing. The national average of conventional eggplant production in the open field is 10 tons/ha [1]. So, it is quite higher than the commercially grown any variety in open condition. Other bagging fruits viz., local brown bag (46.74 t/ha), HDPE bag (45.00 t/ha), butter paper bag (43.23 t/ha).

No infection by eggplant fruit and shoot borer (EFSB) was observed in imported brown bag, imported white bag and butter paper bag, which ensures higher fruit production with higher quality. But the bagging materials were different in nature, so there was a variation in fruit skin colour. Imported brown bagged fruit produced white skin colored fruit which was abnormal colour will not popular to the consumer. So, imported white bag and butter paper bag will be the best option to protect EFSB infection with true to colour of fruits. There were no scratched fruits observed in these two bagging types. So, by following these bagging materials, safe eggplant can be produced without spraying of toxic insecticides. This bagging system can be adopted in organic eggplant production practices. Safe brinjal bring prices $199 \%$ higher than conventionally brinjal grown, which can more than compensate for the difficulties encountered when producing organic brinjal and other organic vegetables [9].

TABLE I: EFFECT OF DIFFERENT BAGGING MATERIALS ON YIELD AND YIELD CONTRIBUTING CHARACTERS

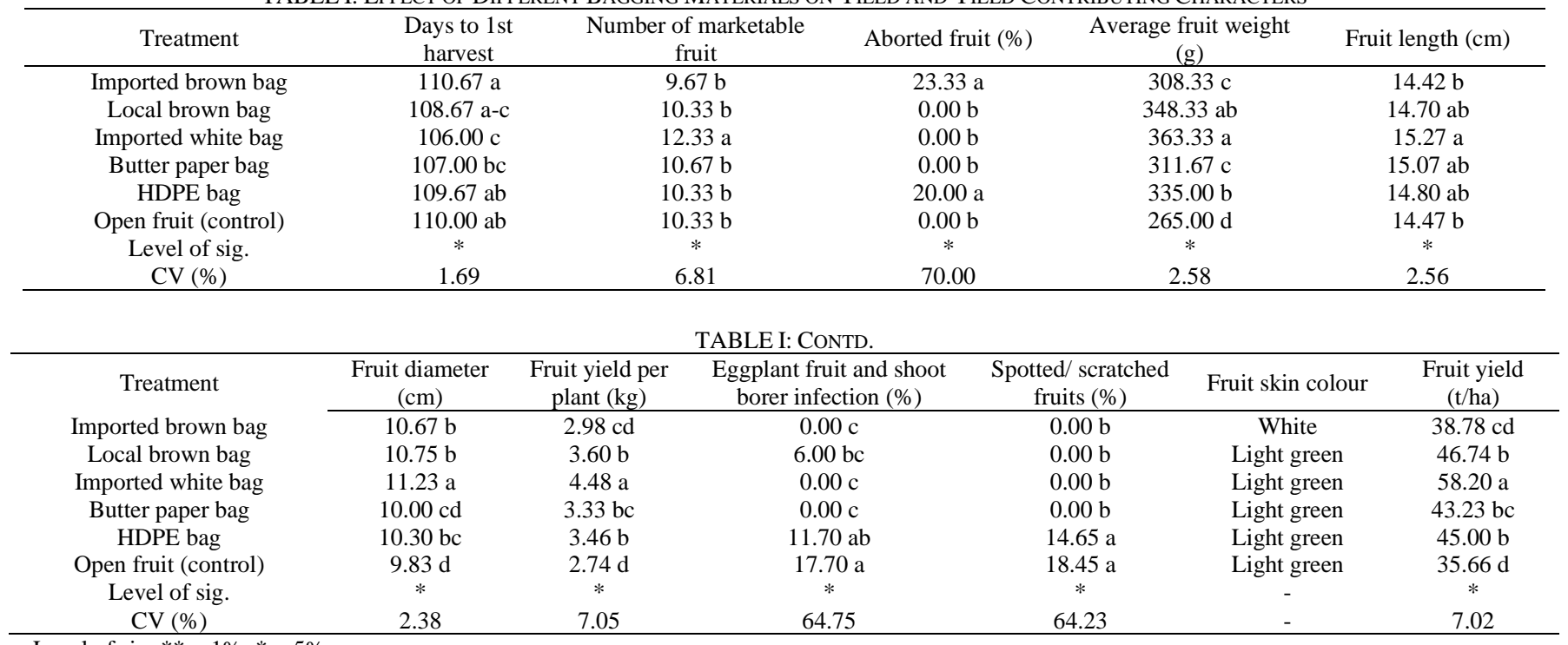

Level of sig. $* *=1 \% ; *=5 \%$.

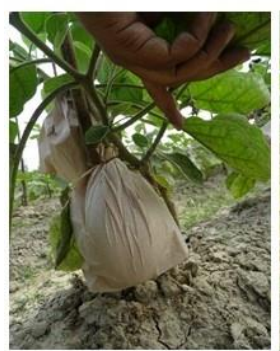

Imported brown

bag
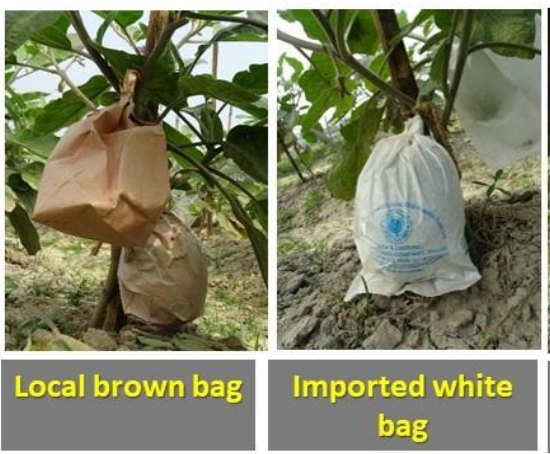
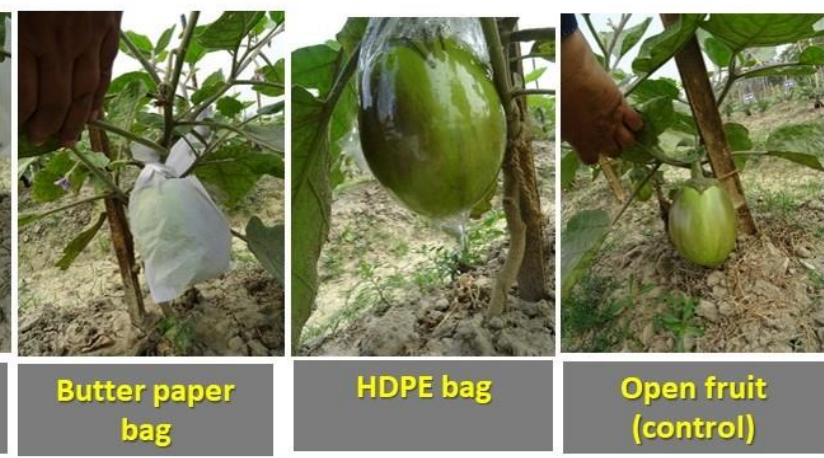

Fig. 1. Field performances with different bagging materials on fruit eggplant fruit yield. 


\section{CONCLUSION AND RECOMMENDATION}

The bagging of eggplant fruits with imported white bag and butter paper bag were more effective in reducing damage by eggplant fruit and shoot borer than the other bagging treatments and the control. These two treatments produced higher number of consumers preferred fruit, without negative effects on the color of the skin, fresh weight and fruit abortion, thus resulting in higher economic gains. Bagging of eggplant fruits with the imported white bag material reused for minimum 3 consecutive seasons can provide an economic gain similar to those of bagging with butter paper bag. In addition to economic profitability, bagging eggplant fruits has major environmental benefits.

\section{ACKNOWLEDGEMENT}

This work was supported by the core fund of Bangladesh Agricultural Research Institute to complete this work.

\section{REFERENCES}

[1] Anonymous. 2020. Year Book of Agricultural Statistics of Bangladesh 2018. Bangladesh Bureau of Statistics, Ministry of Planning, Government of Peoples Republic of Bangladesh, Dhaka, Bangladesh. pp 249-290.

[2] Anonymous. 1995. Agro-climatatrological data. Agromet Division, Bangladesh Meteorological Department, Joydebpur, Gazipur. pp. 3565.

[3] Gomez, K. A. and Gomez, A A. 1984. Statistical Procedure for Agricultural. Research (2nd edition). Int. Rice Res. Inst. A Willey Int. Sci. Pub. pp.28-192.

[4] Lebedenco A. 2006. Eficiência de métodos de controle de pragas do tomateiro (Lycopersicom esculentun Mill) na região de Presidente Prudente. 51 f. Dissertação (Mestrado em Agronomia) - Universidade do Oeste Paulista - UNOESTE, São Paulo.

[5] Gualberto R, Braz L T, and Banzatto D A. 2002. Produtividade, adaptabilidade e estabilidade fenotípica de cultivares de tomateiro sob diferentes condições de ambiente. Pesqui. Agropec. Brasileira 37: 8188.

[6] Rodrigues Filho IL.2001. Estudo da viabilidade do uso do ensacamento de pencas em tomateiro tutorado como alternativa ao controle de Neoleucinodes elegantalis (Guenée, 1854) (Lepidoptera: Crambidae) Paty do Alferes - RJ. 2000. 105.

[7] Jordão A L and Nakano O. 2002. Ensacamento de frutos do tomateiro visando ao controle de pragas e à redução de defensivos. Sci. Agr. 59: 281-289.

[8] Leite GLD, Souza MF, Souza PNS, Fonseca MM and Zanuncio JC, 2012. The bagging of Annona crassiflora fruits to control fruit borers. Acta Sci. Agron. 34: 253-257).

[9] Martins VA, Waldemar Filho PC and Bueno CRF, 2006. Preços de frutas e hortaliças da agricultura orgânica no mercado varejista da cidade de São Paulo. Inf. Econ. 36: 42-51.

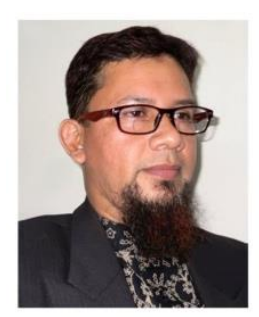

AKM Quamruzzaman born in Dhaka, Bangladesh and got $\mathrm{PhD}$ degree in Horticulture major with Vegetables Breeding from Bangabandhu Sheikh Mujibur Rahman Agricultural University (BSMRAU) in 2011. At present he is currently employed as PRINCIPAL SCIENTIFIC OFFICER at Olericulture Division, BARI, Gazipur, Bangladesh. As a vegetable scientist, he is the principal breeder of Solanaceous and Cucurbitaceous vegetables research. He developed more than 25 vegetables varieties and published more than 80 scientific articles. Dr. Quamruzzaman is an active member of American Society for Horticultural Science (ASHS), Bangladesh Society for Horticultural Science (BSHS), Plant Breeding and Genetics Society of Bangladesh (PBGSB) and also serving as project investigator of FAO, AFACI, WordVeg, NATP, SACP-IFAD.

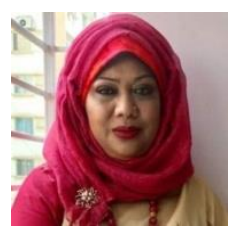

Ferdouse Islam born in Naogaon, Bangladesh and got $\mathrm{PhD}$ degree in Horticulture major with Vegetables production From BAU in 2009. At present he is currently employed as CHIEF SCIENTIFIC OFFICER and at Olericulture Division, BARI, Gazipur, Bangladesh. She is the head of vegetables research at her institute, developed 15 vegetables varieties and published more than 30 scientific articles. Dr. Islam is an active member of BSHS, BAS and KIB and also serving as project coordinator of FAO, AFACI, WordVeg, NATP.

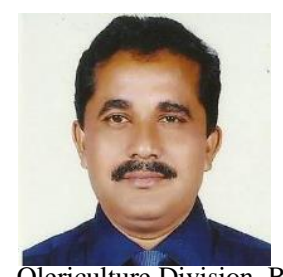

Md. Nazim Uddin born in Netrokona, Bangladesh and got $\mathrm{PhD}$ degree in Horticulture from Bangabandhu Sheikh Mujibur Rahman Agricultural University (BSMRAU) in 2008 and Post-doctoral Fellow (UNU -Kirin Fellowship Japan) in the Food Research Institute, NARO, Tsukuba, Japan. At present he is currently employed as SENIOR SCIENTIFIC OFFICER at Olericulture Division, BARI, Gazipur, Bangladesh. As a vegetable scientist, he is the principal scientist of organic vegetables research. He developed more than 15 vegetables varieties and published more than 42 scientific articles. Dr. Nazim Uddin is an active member of Bangladesh Society for Horticultural Science (BSHS), Plant Breeding and Genetics Society of Bangladesh (PBGSB) and also serving as project investigator of AFACI, WordVeg, KGF.

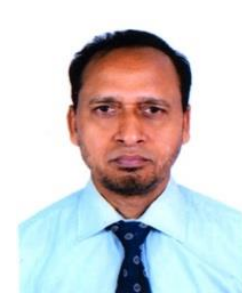

Md. Shahadath Hossain born in 1967 at Mymensingh, Bangladesh and got $\mathrm{PhD}$ degree in Entomology major with Integrated Pest management (IPM) From BSMRAU in 2009 At present he is employed as PRINCIPAL SCIENTIFIC OFFICER at HRC, BARI, Gazipur, Bangladesh. As an entomologist, he is engaged in fruits and vegetables IPM research. He developed more than 18 technologies on pest management and published more than 50 scientific articles. He worked in IPM IL, Virginia Tech and International Potato Center (CIP) as Assistant Coordinator and IPM Coordinator during 2014 and 2015, respectively. Dr. Hossain is the life member of Entomological Society, PBGSB and also serving as Principal investigator of Krishi Gobeshana Foundation (KGF) and IPM IL, Virginia Tech, USA projects. In 2020, he won International IPM award for his great contribution to Integrated Pest management internationally. 